\title{
Pearls and pitfalls in the diagnosis of adult celiac disease
}

\author{
Hugh J Freeman MD
}

HJ Freeman. Pearls and pitfalls in the diagnosis of adult celiac disease. Can J Gastroenterol 2008;22(3):273-280.

In adults with diarrhea or suspected malabsorption, a diagnosis of celiac disease requires that two criteria be fulfilled: first, a demonstration of typical pathological changes of untreated disease in biopsies from the proximal small bowel; and second, evidence should exist that clinical (and/or pathological) changes are gluten-dependent, most often as an unequivocal response to a gluten-free diet. Pathological abnormalities of celiac disease may include severe ('flat') or variably severe (mild or moderate) small bowel mucosal architectural abnormalities that are associated with both epithelial cell and lymphoid cell changes, including intraepithelial lymphocytosis. Architectural changes tend to be most severe in the duodenum and proximal jejunum and less severe, or absent, in the ileum. These findings, while characteristic of celiac disease, are not specific because several other conditions can produce similar changes. Some serological assays (eg, tissue transglutaminase antibody assays) are very useful screening tools in clinical practice because of their high specificity and sensitivity, but these do not provide a definitive diagnosis. The most critical step in the diagnosis of celiac disease is the demonstration of its gluten-dependent nature. The clinical response to gluten restriction in celiac disease is usually reflected in the resolution of diarrhea and weight gain. Normalization of biopsy changes can be first shown in the most distal intestinal sites of involvement, and later, sometimes only after prolonged periods (months to years) in the duodenum. Rarely, recurrent (or refractory) celiac disease may occur after an initial gluten-free diet response. Finally, some with 'sprue-like intestinal disease' cannot be classified because a diet response fails to occur. This may be a heterogeneous group, although some are eventually found to have a malignant lymphoma.

Key Words: Celiac disease; Celiac sprue; Gluten-free diet; Glutensensitive enteropathy; Small bowel biopsy; Tissue transglutaminase

\section{Les perles et les écueils dans le diagnostic de la maladie coeliaque}

Chez les adultes atteints de diarrhée ou chez qui on présume une malabsorption, il faut respecter deux critères pour diagnostiquer une maladie cœliaque : d'abord, la démonstration des changements pathologiques classiques de la maladie non traitée dans les biopsies prélevées dans l'intestin grêle proximal, puis la démonstration que ces changements cliniques (ou pathologiques) dépendent du gluten, le plus souvent en réponse non équivoque à un régime sans gluten. Les anomalies pathologiques de la maladie cœliaque peuvent inclure des anomalies architecturales graves (plates) ou à la gravité variable (moyenne ou modérée) de la muqueuse de l'intestin grêle, reliées aux changements des cellules épithéliales et lymphoïdes, y compris la lymphocytose intra-épithéliale. Les changements architecturaux ont tendance à être plus graves dans le duodénum et le jéjunum proximal et moins graves, ou inexistants, dans l'iléon. Ces observations, même si elles sont caractéristiques de la maladie coliaque, ne sont pas spécifiques, car plusieurs autres maladies peuvent produire des changements similaires. Certaines analyses sérologiques (p. ex., analyses des anticorps de la transglutaminase des tissus) sont des outils de dépistage très utiles en pratique clinique en raison de leur spécificité et sensibilité élevées, mais elles ne fournissent pas un diagnostic définitif. Le fait de démontrer la dépendance au gluten de la maladie constitue l'étape la plus importante pour diagnostiquer la maladie cœliaque. En général, la réponse clinique à la restriction du gluten dans la maladie cœliaque se reflète par la résolution de la diarrhée et une prise de poids. On constate la normalisation des changements aux biopsies d'abord dans les foyers intestinaux les plus distaux de l'atteinte, puis, plus tard et parfois seulement après une période prolongée (mois ou années), dans le duodénum. Dans de rares cas, on observe une maladie coliaque récurrente (réfractaire) après une réponse initiale à un régime sans gluten. Enfin, certaines personnes atteintes d'une entéropathie spruiforme ne peuvent être classées parce qu'elles ne répondent pas au régime. Il peut s'agir d'un groupe hétérogène, mais on finit par découvrir, chez certains, un lymphome malin.
A dult celiac disease has become increasingly recognized in North America (1), even in primary care settings (2). Detection may be straightforward, but several pitfalls contribute to under-diagnosis as well as over-diagnosis. Adult celiac disease requires differentiation from other disorders, some common, but not gluten-sensitive, because some mimic its clinical and histological appearance. Rarely, celiac disease can become refractory or, from the outset, resistant to treatment. In these cases, more sinister disorders, such as lymphoma, may develop or may already be present.

Referred patients often have chronic diarrhea for more than one month, with negative fecal studies for bacterial pathogens and parasites. Medical texts provide algorithms on costly and time-consuming diagnostic tests. Some are patient-dependent, require timed collections and are difficult to do with laboratory precision. Often, these may be circumvented with early endoscopic small bowel biopsies. Some may have no diarrhea or weight loss. Instead, iron deficiency or altered chemistry values (eg, low serum folate or albumin levels) occur. Alternatively, a disorder closely linked to celiac disease may be initially diagnosed (eg, autoimmune thyroid disease, insulin-dependent diabetes and dermatitis herpetiformis). Finally, positive screening blood tests (eg, antibodies to tissue transglutaminase) may lead to suspicion of celiac disease. The pathological changes found in celiac disease have been extensively detailed and illustrated elsewhere with representative photomicrographs $(3,4)$.

A definitive diagnosis is sometimes difficult because there are many pitfalls. Because diagnosis is pathologically based, the clinician may benefit from a 'hands-on' training experience in intestinal biopsy interpretation and an ongoing interaction

Department of Medicine (Gastroenterology), University of British Columbia, Vancouver, British Columbia

Correspondence: Dr Hugh Freeman, Gastroenterology, UBC Hospital, 2211 Wesbrook Mall, Vancouver, British Columbia, Canada V6T 1W5.

Telephone 604-822-7216, fax 604-822-7236, e-mail hugfree@shaw.ca

Received for publication September 25, 2007. Accepted November 1, 2007 


\section{TABLE 1}

\section{Biopsy changes in adult celiac disease}

\section{Severe ('flat') lesion}

Absent or rudimentary villi, crypt epithelial hyperplasia (not hypoplasia), increased crypt epithelial cell mitotic index, increased lymphoid cell content of the lamina propria, intra-epithelial lymphocytosis, cuboidal (rather than columnar) epithelial cells

Other terms include crypt hyperplastic (not hypoplastic) villous atrophy Similar to 'flat destructive' or 'Marsh type 3' lesion

\section{Moderate lesion}

Similar abnormalities, but changes are not as pronounced, with only limited, but definite, alterations in villous architecture

A form of variably severe architectural disturbance

Similar to 'infiltrative hyperplastic' or 'Marsh type 2' lesion

\section{Mild lesion}

Villi remain unaltered or only minimally changed in size with a loss of epithelial cell polarity and marked increase in intraepithelial lymphocytes Lamina propria cellularity may be marginally increased

A form of variably severe architectural disturbance Similar to 'infiltrative' or 'Marsh type 1' lesion

with expert pathologists. The critical imperative is communication of the clinical problem to pathologists and submission of quality biopsies with their sites precisely noted to optimize evaluation. A clinically relevant pathology report based on the severity of architectural disturbance may be especially valuable.

\section{ENDOSCOPIC CHANGES IN CELIAC DISEASE}

Endoscopic changes in celiac disease reflect the disappearance of normal mucosal patterns. A smooth tubular surface, with 'scalloped' or 'ridged' folds have been reported (5). Similar changes have been described with wireless capsule endoscopy (6). These are not specific to celiac disease and occur in other disorders with duodenal involvement (ie, Crohn's disease) $(7,8)$. Although macroscopic changes can direct the site of biopsy (7), these may be limited and correlate poorly with biopsy changes, including severe ones. Experienced endoscopists estimate that approximately 10\% of cases were diagnosed because screening duodenal biopsies were performed during endoscopic evaluations, not because endoscopic markers were found (9). Conversely, a 'normal' endoscopic appearance is not sufficient to exclude celiac disease. Newer small bowel methods may prove useful. Capsule studies may help define the macroscopic extent of disease and complications may be better appreciated $(10,11)$. Doubleballoon enteroscopy may emerge as an even more effective tool in selected situations because directed biopsy along the length of the small bowel is possible (12) and pathological changes may be identified that were previously missed by capsule studies (13).

For clinical purposes, biopsies have been classified based on the degree of disturbed architecture, along with specific diagnostic features (3). Several classification methods are available. Some (eg, Marsh classification) have found their way into the clinical realm (14), but intraobserver agreement was reduced (15). Multiple biopsies from separate sites are helpful because some disorders reveal only focal changes in the small bowel (eg, Crohn's disease) (16), while others show diffuse, but variably severe changes (eg, giardiasis). Sampling of normaland abnormal-appearing mucosa is also important, especially if erosions or ulcers are present, because some microscopic changes are best appreciated in less inflamed or reactive mucosa (eg, malignant lymphoid cells).

\section{BIOPSY PREPARATION AND HANDLING}

Endoscopic duodenal biopsies must be interpreted cautiously because of their smaller size (compared with suction biopsies) and their proximal location. Acceptable biopsy material may be obtained for diagnostic evaluation, but larger biopsies are better $(17,18)$. Biopsies from the duodenal bulb may have shorter villi with 'pseudoflattened' mucosa overlying Brunner's glands (ie, so-called 'Brunner's gland artifact'), but crypt epithelial cell hyperplasia, which is typical of adult celiac disease, is not present. Also, biopsies showing 'chronic duodenitis' or 'nonspecific inflammation' in the duodenal bulb could be due to celiac disease but these usually reflect pepticrelated disease or drug-induced injury (eg, nonsteroidal antiinflammatory drugs). Indeed, a number of other diseases should be considered (eg, Crohn's disease), especially if changes are found in the distal small bowel.

Artifacts result from specimen handling in the endoscopy suite or with laboratory processing. Technical trauma may be due to the biopsy procedure (eg, so-called 'biopsy crush artifact'). These are more frequent if small specimens are obtained, if multiple biopsies are obtained with a single pass to expedite the speed of the procedure and if biopsies 'tear tissue' with dull or traumatized forceps. Specimens teased from the forceps cup with a narrow-gauge needle or toothpick should be transferred gently to filter paper or monofilament mesh with a 'mucosa side-up' orientation before immersion in a fixative. Specimens should always be submitted in separate containers, each with the precise small bowel site defined, not as a mixture of multiple biopsies from different sites in a single container.

Poor specimen orientation may also occur during paraffin block preparation for serial sectioning. 'Tangential artifact' results may occur if sections are taken external to the biopsy core. This artifact is also more prone to occur if multiple biopsies are embedded in a single block because individual biopsies are technically difficult to precisely orient in the same plane, even by an expert technician. While only a single biopsy may be sufficient, multiple biopsies from different sites are optimal. In special circumstances (eg, recurrent symptoms in established celiac disease), biopsies from multiple sites along the length of the small bowel, using a longer instrument (eg, a hydraulic tube, colonoscope or double-balloon enteroscope), may be required. In one study (19) with patients with celiac disease along with lymphomas, only one of 88 biopsies had malignant cells (19).

\section{CLASSICAL CELIAC DISEASE}

Diarrhea, weight loss and malabsorption commonly occur in classical celiac disease. Pathological changes are typically present in the proximal small bowel (Table 1). Usually, a 'severe ('flat') mucosal lesion' is found (Figures 1 and 2). Indeed, the most common cause of a severe mucosal lesion in western countries is celiac disease (3). Similar changes have been labelled the 'flat destructive' or 'Marsh type 3 lesions' (14). Villi are absent or rudimentary. Increased lamina propria lymphoid cell elements (specifically plasma cells and lymphocytes) and increased intraepithelial lymphocytes are seen. Surface 


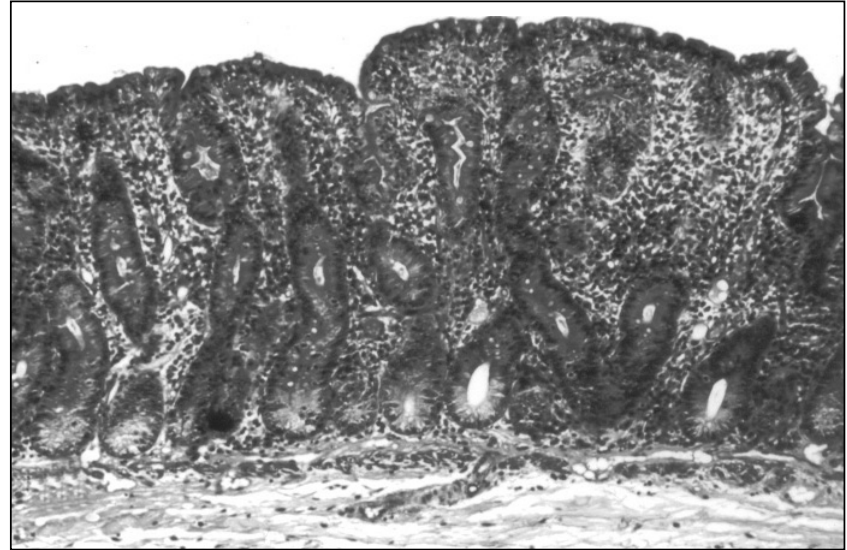

Figure 1) Severe 'flat' mucosal lesion shown in a biopsy section from the region of the Trietz ligament. Villi are rudimentary and atrophic, with elongated hyperplastic crypts. The cellularity of the lamina propria is increased and numerous crypt mitotic figures are seen. These changes are characteristic of, but not specific to, adult celiac disease (hematoxylin and eosin stain; original magnification $\times 75$ )

epithelium is more cuboidal (rather than columnar). Crypt epithelial cell hyperplasia occurs along with an increased mitotic index. Subcellular changes (eg, increased epithelial vacuolization) and altered glycocalyx (ie, shown with lectins) may occur (20). With a strict gluten-free diet, these changes revert toward normal (Figure 3). Comparable proximal small bowel sites will eventually show histological improvement, although prolonged periods may be needed, particularly in older adults (21). Villi reappear and crypt mitotic indices normalize. Lamina propria cellularity and numbers of intraepithelial lymphocytes become reduced toward normal.

In some, lesser degrees of altered villous architecture occur (3). Due to an increased use of serological screening tests, these are frequently appreciated (ie, the so-called 'celiac iceberg'). With the 'mild lesion', villi remain largely unchanged or minimally altered. Abnormal epithelium may be seen with loss of polarity and increased intraepithelial lymphocytes. Changes are similar to the 'infiltrative' or 'Marsh 1 lesion' (14). For the 'moderate lesion', definite villous architectural changes occur. These may be classified as an 'infiltrative hyperplastic' or 'Marsh 2' lesion (14). Variably severe changes may be present in celiac disease, dermatitis herpetiformis $(22,23)$ and intestinal lymphoma $(24,25)$. Similar findings are reported in asymptomatic first-degree relatives (26).

Less severe architectural changes should prompt investigation for a nonceliac cause, including infections (eg, giardiasis and cryptosporidiosis). Epithelial lymphocytosis alone, with normal small bowel architecture may show a favourable clinical response to a gluten-free diet (approximately 10\%), suggesting that increased intraepithelial lymphocyte counts may indicate adult celiac disease (27). Some have reported that diagnosis may even be possible without these changes, using only immunohistochemical markers to label intraepithelial lymphocytes (28-30).

Small bowel changes in adult celiac disease also occur in another dimension - along the length of the small bowel. Previously, these were detected using suction instruments to procure biopsies in the more distal small bowel (eg, a multipurpose tube for multiple same-site biopsies and a Quinton

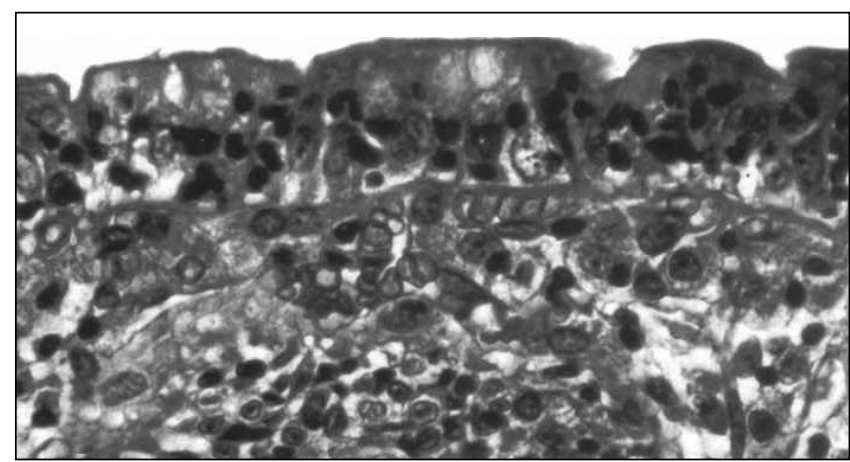

Figure 2) Higher power view of the same biopsy shown in Figure 1. Increased numbers of intraepithelial lymphocytes are seen (hematoxylin and eosin stain; original magnification $\times 250$ )

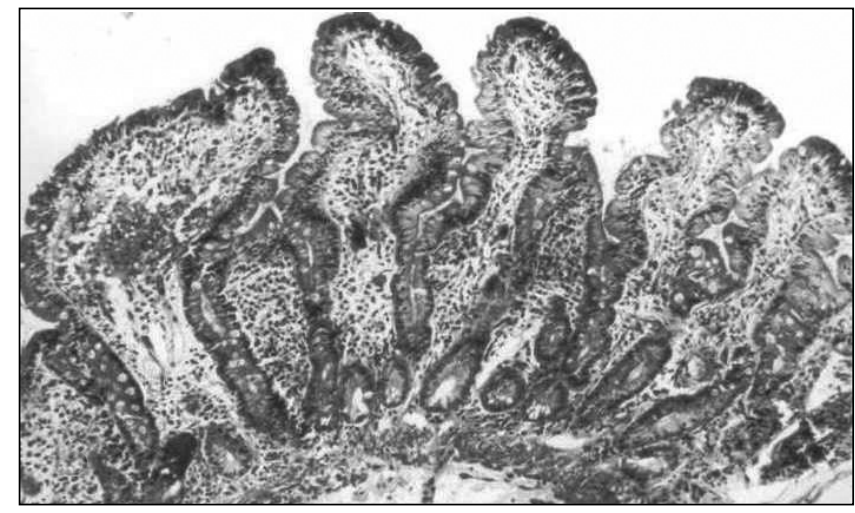

Figure 3) Post-treatment small intestinal biopsy section from a similar biopsy site shown in Figures 1 and 2, obtained eight weeks after initiation of a strict gluten-free diet. There is normalization of the abnormal architectural changes. Villi are elongated with shorter crypts. Fewer mitotic figures are seen. Lamina propria cellularity is markedly reduced. Epithelial cells are more columnar and intraepithelial lymphocyte numbers are reduced. This gluten-free diet response is characteristic of biopsy-defined celiac disease (hematoxylin and eosin stain; original magnification $\times 75$ )

hydraulic tube for different sites). Newer technologies now permit further visualization along the length of the small intestine, including some emerging methods (eg, capsule and double-balloon enteroscopic studies).

Changes along the length of the small bowel in patients with celiac disease are important. First, their extent, rather than their severity, correlates better with clinical status. In classical celiac disease with diarrhea, malabsorption and weight loss, severe changes may extend beyond the proximal jejunum. In the ileum, variably severe, often patchy changes may also occur or the mucosa may be normal. Interestingly, even with a malignant ileal lymphoma (and coexisting adjacent normal ileal mucosa), severe biopsy changes were still present in the proximal intestine (24). Conversely, ileocolonoscopic biopsies cannot exclude adult celiac disease and rarely, if ever, are diagnostic. However, increased ileal intraepithelial lymphocyte counts should prompt proximal small bowel biopsies to exclude celiac disease $(31,32)$. Possibly, this 'proximalto-distal gradient' in severity of the pathological changes reflects higher concentrations of dietary gluten (or its derivative 
peptides) in the proximal small bowel. Alternatively, these could represent 'indirect' changes, reflecting immunemediated effects driven by recirculating memory T-cells (33). Second, earlier studies showed that most of the distal ileum in celiac disease is still exquisitely sensitive to gluten peptides infused through long intestinal tubes (34). With extensive disease, diarrhea and malabsorption of many nutrients may result. With less extensive involvement, deficits may be limited and diarrhea or weight loss may not be evident. In some, only isolated iron deficiency may be present, due in part to the major localization of celiac disease in the duodenum, the principal site for iron absorption. Third, a gluten-free diet causes clinical improvement (ie, resolution of diarrhea and weight gain) that reflects improved absorption along the length of the small bowel. Concomitant with this improved clinical state, however, the resolution of histological changes occurs first in the distal and later, in the proximal small bowel. To verify the response to a gluten-free diet, prolonged periods of gluten restriction may be required, even months or years, before normalization of the proximal duodenal mucosa can be documented (35). Biopsies from duodenal sites after a patient has been on a strict gluten-free diet for only a limited period of time may not be sufficient to show a histological response, even if clinical improvement occurs. Some patients may be erroneously diagnosed with 'refractory' celiac disease even though the expected diet-induced response has started, but only in the distal small bowel.

\section{CRITERIA FOR CELIAC DISEASE DIAGNOSIS}

A clinical diagnosis of celiac disease requires that two specific criteria be fulfilled: first, typical biopsy changes of untreated celiac disease in the proximal small bowel should be present; and second, dietary gluten restriction should lead to improvement. Most often, in adults, an improved clinical state with resolution of diarrhea and weight gain may be sufficient to provide a convincing clinical diagnosis. In some, however, with a paucity of symptoms, additional biopsies may be needed to show pathological improvement in the small bowel. Importantly, more than $50 \%$ of celiac disease patients would now be classified as overweight or obese (36). In these patients, weight gain also occurrs with a gluten-free diet (36). Serological tests (eg, antibodies to endomysium or tissue transglutaminase) are useful to screen for adult celiac disease, but are not adequate for diagnosis alone (37). Moreover, these tests should not be used as the sole method to monitor intestinal recovery $(38,39)$. Falsely negative serological tests do occur. Some are due to an associated serum immunoglobulin A deficiency (40). If an adult with chronic diarrhea or malabsorption is clinically suspected of having celiac disease, then small bowel biopsy should be done to exclude the disorder, even without serological results. If serological screening tests are positive, a biopsy should be taken to determine whether the serologically based suspicion of celiac disease was correct, because false-positive results also occur. Some seropositive patients may have entirely normal small bowel biopsies (with no increase in intra-epithelial lymphocytes) indicating that true false-positives occur (41).

\section{OCCULT AND LATENT CELIAC DISEASE}

Diagnosis of celiac disease may be delayed, even into late adult years (42). Severe histological changes may be documented, but only in the most proximal small bowel. In some with occult (or 'silent') celiac disease, only isolated deficiencies of specific nutrients (ie, iron, folic acid and calcium) may develop without diarrhea or weight loss $(42,43)$. Others have dermatitis herpetiformis $(22,23)$, autoimmune forms of thyroid disease (44), insulin-dependent diabetes (45), small intestinal carcinoma (46) or lymphoma $(47,48)$. Usually, T-cell lymphomas occur in intestinal sites (47) but nonintestinal sites may also harbour lymphomas in cases of occult celiac disease, such as the liver and spleen (ie, hepatosplenic lymphoma) (48), and the thyroid gland (49). Rarely, a dramatic presentation may occur with free intestinal perforation due to a complicating malignant lymphoma (50). Celiac disease occurs with 'new' forms of inflammatory mucosal disease, including collagenous colitis (51), lymphocytic colitis (52), lymphocytic sclerosing cholangitis (53), and collagenous and lymphocytic gastritis $(54,55)$. Although clinically and pathologically heterogeneous, all share a common histological feature with celiac disease - increased numbers of intraepithelial lymphocytes (56). Interestingly, serological testing for endomysial or tissue transglutaminase antibodies has failed to increase detection of celiac disease in either lymphocytic or collagenous colitis (57). Moreover, feeding diets that are high in gluten to patients with lymphocytic colitis does not elicit small bowel biopsy changes of celiac disease (58). However, in consecutive collagenous colitis cases, more than $20 \%$ of patients had celiac disease (59).

Another adult form is latent celiac disease, initially reported in dermatitis herpetiformis (60) and later, in small bowel lymphoma (25). In latent disease, the architecture of the small intestine was normal. However, a high-gluten diet provoked pathological changes of variable severity, indicating that the small bowel mucosa was gluten-sensitive. These changes have not been detected in normal volunteers fed similar gluten-containing diets. Moreover, these gluten-induced small bowel changes in latent celiac disease were also shown to respond to treatment with a gluten-free diet.

A clinical pitfall may be caused by a report of 'minimal' or 'mild' change, 'compatible with (or consistent with) celiac disease'. If symptoms or laboratory tests characteristic of malabsorption are evident, there should be more than 'mild' or 'nonspecific' biopsy changes. Epithelial lymphocytosis alone, without architectural change is not sufficient. Instead, if only minimal changes are present, a number of possibilities should be considered. First, celiac disease could be present, but some other disorder might be responsible for the symptoms. Second, normal mucosa could have been labelled incorrectly with mild changes. The results of a false-positive histological diagnosis of celiac disease are not minimal. Major lifestyle adjustments and increased costs of maintaining a gluten-free diet result. There are also other future considerations (eg, bone demineralization and risk of lymphoma). Some patients with only mild or moderate villous architectural changes could still have celiac disease $(28,61)$. However, a definitive diagnosis requires that the mucosal changes are gluten-sensitive. Gluten challenge may be helpful if only limited or mild abnormalities are initially present (62). Some with symptoms attributed to gluten ingestion (or more likely, wheat) have normal small bowel biopsies. Often, despite reintroduction of dietary gluten, even for prolonged periods, small bowel biopsies remain normal. In these cases, some other cause is responsible for symptoms, such as a functional disorder. A diagnosis of celiac disease cannot be established without evidence of gluten-sensitive mucosal changes. 
TABLE 2

Adult sprue syndromes

\begin{tabular}{ll}
\hline Disorder & Treatment \\
\hline Celiac disease* (classical, occult, latent) & Gluten-free diet \\
Oats-induced villous atrophy & Oats restriction \\
Refractory sprue (refractory celiac disease) & Not known \\
Collagenous sprue & Not known \\
Mesenteric lymph node cavitation syndrome & Not known \\
Other protein injury (soy, milk or other protein) & Delete specific \\
& protein \\
Unclassified sprue (sprue-like intestinal disease) & Not known
\end{tabular}

Each of these adult sprue syndromes may cause severe ('flat') or variably severe biopsy lesions. Refractory celiac disease requires evidence of an initial response to a gluten-free diet. In patients with unclassified sprue (or sprue-like intestinal disease), no response to a gluten-free diet was documented. *Other terms for celiac disease include gluten-sensitive enteropathy or celiac sprue

\section{OTHER CAUSES OF SEVERE ('FLAT') OR VARIABLY SEVERE LESIONS}

Other causes of severe or variably severe small bowel biopsy lesions may be associated with diarrhea or malabsorption (Tables 2 and 3). However, only celiac disease responds to a gluten-free diet. Oats may be safely consumed (63), but can also be contaminated by other grains. In addition, oats alone may induce abnormalities in villous architecture (64).

Infections can produce severe changes. However, these usually respond to antibiotics and are temporary. Occasionally in adults, but more often in children, severe changes may occur without detection of an infection. Possibly, these are due to an undetected viral agent or an infection that spontaneously resolved without treatment (65-67). In adults, variable changes may also occur. For example, in cases of giardiasis, which is a common protozoan infection, up to $15 \%$ of patients may have changes that are so architecturally abnormal that they mimic the severest changes found in celiac disease, at least until the organisms are actually recognized (either in fecal or biopsy specimens).

Other protozoans should also be routinely excluded. A definition of the adult forms, their trophozoites or an intracellular part of the life cycle may lead to a diagnosis (eg, Isospora belli, Cryptosporidium paruum, Cyclospora cayetanensis and other microsporidians (ie, Enterocytozoon bieneusi). Some infections occur with immune deficiency syndromes following transplants or HIV infection (68). Multiple agents may make a definition of the precise cause of pathological changes impossible. Parasites may also cause severe changes, but distinctive agents are usually present (eg, Strongyloides stercoralis, hookworm, Schistosoma or Capillaria species). In some cases, histopathological changes may mimic eosinophilic enteritis, a diagnosis that is only established after exclusion of parasites. Viral agents (ie, cytomegalovirus) may be seen in the small bowel, often with immune compromise (69). HIV-infected patients may display a wide array of mucosal changes, from severe to variably severe alterations. It is not certain whether the viral agent per se causes pathological changes, or whether changes are indirect, possibly related to immunological dysfunction, malnutrition or some other infection (68). Fungal agents, including Candida species and histoplasmosis, can also be detected in the small bowel (70). Small intestinal stasis (or contamination) syndromes (ie, bacterial overgrowth) that are associated with

\section{TABLE 3}

Causes of sprue-like biopsy changes

\begin{tabular}{|c|c|}
\hline Disorder & Treatment \\
\hline \multicolumn{2}{|l|}{ Infectious disorders } \\
\hline Infectious gastroenteritis (rarely in adults) & Spontaneous resolution \\
\hline $\begin{array}{l}\text { Infections (eg, parasite, protozoan or } \\
\text { mycobacteria) }\end{array}$ & Treat specific infection \\
\hline Tropical sprue & Antibiotics and folic acid \\
\hline $\begin{array}{l}\text { Stasis syndrome (contaminated bowel } \\
\text { syndrome) }\end{array}$ & Antibiotics \\
\hline Whipple's disease & Antibiotics \\
\hline \multicolumn{2}{|l|}{ Deficiency syndromes } \\
\hline Nutrients (zinc, vitamin $\mathrm{B}_{12}$ and folic acid) & Replace specific nutrient \\
\hline Kwashiorkor and malnutrition syndromes & Adequate dietary protein \\
\hline Immunodeficiency syndromes & Not known; treat infections \\
\hline \multicolumn{2}{|l|}{ Others } \\
\hline Intestinal lymphangiectasia & Not known \\
\hline Crohn's disease (including the duodenum) & $\begin{array}{l}\text { Treat symptoms; cause } \\
\text { unknown }\end{array}$ \\
\hline Graft versus host disease & Graft rejection therapy \\
\hline Immunoproliferative disease (lymphoma) & Usually chemotherapy \\
\hline Macroglobulinemia & Usually chemotherapy \\
\hline $\begin{array}{l}\text { Zollinger-Ellison syndrome with increased } \\
\text { acid }\end{array}$ & Antisecretory therapy \\
\hline $\begin{array}{l}\text { Drug-induced small bowel injury } \\
\text { (eg, nonsteroidal anti-inflammatory drugs) }\end{array}$ & Remove offending agent \\
\hline
\end{tabular}

altered motility may cause severe architectural changes. Distinctive findings also occur with Mycobacterium aviumintracellulare infection with clusters of foamy macrophages containing acid-fast organisms leading to an expanded lamina propria $(71,72)$. These changes are reminiscent of Whipple's disease with distended lacteals due to periodic acid-Schiff stain-positive macrophages, except that with Whipple's disease, acid-fast stains are negative.

Other disorders may cause diarrhea and/or malabsorption with severe or variably severe architectural changes. In some disorders, distinct features are evident, such as lymphoma, lymphangiectasia (73), macroglobulinemia (74), amyloidosis (75), abetalipoproteinemia (76), some lipid storage disorders, such as Fabry disease (77), radiation injury and drugs (eg, triparanol, neomycin, busulfan, methotrexate, sulindac and azathioprine $(78,79)$. Although Crohn's disease may cause a granulomatous mucosal reaction (80), a severe mucosal biopsy lesion without granulomatous change, similar to untreated celiac disease, may occur in the proximal small bowel (16). In cases of Crohn's disease, these findings fail to improve with a gluten-free diet.

\section{REFRACTORY CELIAC DISEASE}

In celiac disease, diarrhea or malabsorption may recur. Even though improved histology may have been initially defined after a gluten-free diet, severe and diffuse pathological changes redevelop. In most patients, diet compliance has been poor. Alternatively, gluten ingestion was inadvertent. Gluten is ubiquitous, recognized only later in some ingested items (eg, pill capsules and communion wafers). Possibly, tolerance to specific toxic gluten peptides varies among different individuals or a minimum threshold exists in some populations (81). 
Alternatively, a superimposed infection or deficiency of one or more nutrients (eg, folic acid and zinc) causes independent morphological changes. In long-standing celiac disease, pancreatic exocrine insufficiency may also occur, especially if severe concomitant malnutrition is present (35). Retracing the steps that led to the original diagnosis may be necessary to ensure that the initial diagnosis was correct. Finally, another disorder (eg, collagenous colitis) or a sinister complication (ie, lymphoma) (82) could cause recurrent symptoms.

Rarely, an unusual disorder - collagenous sprue - may complicate celiac disease (83). Panmalabsorption with diarrhea, weight loss, electrolyte abnormalities and marked nutritional disturbance occur, and mucosal biopsies show a pathologically distinctive subepithelial band of collagen. Some need longterm support with parenteral nutrition to survive. Antibodies to endomysium in collagenous sprue provide an immunological link to celiac disease (84). Rarely, lymphoma may also supervene $(85,86)$.

Occasionally, an unusual syndrome may complicate celiac disease with recurrent small bowel changes of variable severity, splenic hypofunction and mesenteric lymph node cavitation (87). In this disorder, lymphoma has also been recorded (19).

\section{UNCLASSIFIED SPRUE OR SPRUE-LIKE INTESTINAL DISEASE}

Unclassified sprue (or sprue-like intestinal disease) refers to a severe ('flat') or variably severe (moderate or mild) mucosal lesion that has not shown responsiveness to gluten restriction.
Some have been labelled 'refractory celiac disease', usually because repeated small bowel biopsies remain abnormal despite a gluten-free diet. However, in some, dietary compliance has been difficult to prove. Evidence of failed histological improvement is marginal, often based largely on endoscopic duodenal biopsies alone. This group likely represents a heterogeneous collection of small bowel disorders, a 'wastebasket group' with no defined cause. Some possibly represent the 'atrophic hypoplastic' or 'Marsh 4 lesion' described elsewhere (14). Most remain symptomatic with malabsorption and weight loss, and do not appear to respond to a gluten-free diet. Some may have a 'clinically resistant form' of celiac disease, while others prove to have a difficult-to-diagnose lymphoma (3). In some with 'refractory sprue', an abnormal subset of intraepithelial lymphocytes with morphologically normal, but phenotypically abnormal lymphocytes was reported $(88,89)$. Additional studies are needed to determine whether these intriguing findings represent a prognostic marker of later lymphoma development.

\section{CONCLUSIONS}

Celiac disease is a chronic intestinal disorder that is estimated to affect approximately $0.5 \%$ to $1 \%$ of the North American population. Awareness has increased, but celiac disease still remains markedly under-diagnosed. This may change in the near future due, in part, to the emerging interest in new, potentially alternative treatments to the expensive and inconvenient gluten-free diet (90). Accurate diagnoses of celiac disease will be essential.

\section{REFERENCES}

1. Murray JA, Van Dike C, Plevak MF, Dierkhising RA, Zinsmeister AR, Melton LJ III. Trends in the identification and clinical features of celiac disease in a North American community, 1950-2001. Clin Gastroenterol Hepatol 2003;1:19-27.

2. Catassi C, Kryszak D, Louis-Jacques O, et al. Detection of celiac disease in primary care: A multicenter case-finding study in North America. Am J Gastroenterol 2007;102:1454-60.

3. Lewin KJ, Riddell RH, Weinstein WM. Gastrointestinal Pathology and Its Clinical Implications. Tokyo: Igaku-Shoin Medical Pub, 1992.

4. Whitehead R. Mucosal Biopsy of the Gastrointestinal Tract (Major Problems in Pathology), 5th edn. Philadelphia: WB Saunders Company, 1996.

5. Jabbari M, Wild G, Goresky GA, et al. Scalloped valvulae conniventes: An endoscopic marker of celiac sprue. Gastroenterology 1988;95:1518-22.

6. Hopper AD, Sidhu R, Hurlstone DP, McAlindon ME, Sanders DS. Capsule endoscopy: An alternative to duodenal biopsy for the recognition of villous atrophy in coeliac disease? Dig Liver Dis 2007;39:140-5.

7. Oxentenko AS, Grisolano SW, Murray JA, Burgart LJ, Dierkhising RA, Alexander JA. The insensitivity of endoscopic markers in celiac disease. Am J Gastroenterol 2002;97:933-938.

8. Culliford A, Markowitz D, Rotterdam H, Green PH. Scalloping of duodenal mucosa in Crohn's disease. Inflamm Bowel Dis 2004;10:270-3.

9. Freeman HJ. Survey of gastroenterologists on the diagnosis and treatment of adult patients with celiac disease in British Columbia. Can J Gastroenterol 1998;12:149-52.

10. Culliford A, Daly J, Diamond B, Rubin M, Green PH. The value of wireless capsule endoscopy in patients with complicated celiac disease. Gastrointest Endosc 2005;62:55-61,

11. Daum S, Wahnschaffe U, Glasenapp R, et al. Capsule endoscopy in refractory celiac disease. Endoscopy 2007;39:455-8. (Erratum in 2007;39:672 and 2007;39:1 p following 458).

12. Hadithi M, Al-toma A, Oudejans J, van Bodegraven AA, Mulder CJ, Jacobs M. The value of double-balloon enteroscopy in patients with refractory celiac disease. Am J Gastroenterol 2007;102:987-96.

13. Chong AK, Chin BW, Meredith CG. Clinically significant small bowel pathology identified by double-balloon enteroscopy but missed by capsule endoscopy. Gastrointest Endosc 2006;64:445-9.

14. Marsh MN. Mucosal pathology in gluten sensitivity. In: Marsh MN, ed. Celiac Disease. London: Blackwell Scientific Publications, 1992:136-91.

15. Corazza GR, Villanacci V, Zambelli C, et al. Comparison of the interobserver reproducibility with different histologic criteria used in celiac disease. Clin Gastroenterol Hepatol 2007;5:838-43.

16. Schuffler MD, Chaffee RG. Small intestinal biopsy in a patient with Crohn's disease of the duodenum. The spectrum of abnormal findings in the absence of granulomas. Gastroenterology 1979;76:1009-14.

17. Achkar E, Carey WD, Petras R, Sivak MV, Revta R. Comparison of suction capsule and endoscopic biopsy of the small bowel mucosa. Gastrointest Endosc 1986;32:278-81.

18. Mee AS, Burke M, Vallon AG, Mewman J, Cotton PB. Small bowel biopsy for malabsorption. Comparison of the diagnostic adequacy of endoscopic forceps and capsule biopsy specimens. Br Med J (Clin Res Ed) 1985;291:769-772.

19. Freeman HJ, Chiu BK. Small bowel malignant lymphoma complicating celiac sprue and the mesenteric lymph node cavitation syndrome. Gastroenterology 1986;90:2008-12.

20. Freeman HJ. Topography of lectin binding sites in celiac sprue. Can J Gastroenterol 1992;6:271-6.

21. Tursi A, Brandimarte G, Giorgetti GM, et al. Endoscopic and histological findings in the duodenum of adults with celiac disease before and after changing to a gluten-free diet: A 2-year prospective study. Endoscopy 2006;38:702-7.

22. Brow JR, Parker F, Weinstein WM, Rubin CE. The small intestinal mucosa in dermatitis herpetiformis. I. Severity and distribution of the small intestinal lesion and associated malabsorption. Gastroenterology 1971;60:355-61.

23. Weinstein WM, Brown JR, Parker F, Rubin CE. The small intestinal mucosa in dermatitis herpetiformis. II. Relationship of the small intestinal lesion to gluten. Gastroenterology $1971 ; 60: 362-9$ 
24. Freeman HJ, Weinstein WM, Shnitka TK, Piercey JR, Wensel RH. Primary abdominal lymphoma. Presenting manifestation of celiac sprue or complicating dermatitis herpetiformis. Am J Med $1977 ; 63: 585-594$.

25. Freeman HJ, Chiu BK. Multifocal small bowel lymphoma and latent celiac sprue. Gastroenterology 1986;90:1992-7.

26. MacDonald WC, Dobbins WO III, Rubin CE. Studies on the familial nature of celiac sprue using biopsy of the small intestine. N Engl J Med 1965;272;448-56.

27. Kakar S, Nehra V, Murray JA, Dayharsh GA, Burgart LJ. Significance of intraepithelial lymphocytosis in small bowel biopsy samples with normal mucosal architecture. Am J Gastroenterol 2003;98:2027-33.

28. Arranz E, Bode J, Kingstone K, Ferguson A. Intestinal antibody patterns of celiac disease: Association of gamma/delta $T$ cell receptor expression by intraepithelial lymphocytes, and other indices of adult coeliac disease. Gut 1994;35:476-82.

29. Kaukinen K, Maki M, Partanen J, Sievanen H, Collin P. Celiac disease without villous atrophy. Dig Dis Sci 2001;46:879-87.

30. Jarvinen TT, Kaukinen K, Laurila K, et al. Intraepithelial lymphocytes in celiac disease. Am J Gastroenterol 2003;98:1332-7.

31. Dickey W, Hughes DF. Histology of the terminal ileum in coeliac disease. Scand J Gastroenterol 2004;39:665-7.

32. Hopper AD, Hurlstone DP, Leeds JS, et al. The occurrence of terminal ileal histological abnormalities in patients with coeliac disease. Dig Liver Dis 2006;38:815-9.

33. MacDonald TT. T-cell mediated intestinal injury. In: Marsh MN, ed. Celiac Disease. London: Blackwell Scientific Publications, 1992;283-304.

34. MacDonald WC, Brandborg LL, Flick AK, Trier JS, Rubin CE. Studies of celiac sprue. IV. The response of the whole length of the small bowel to a gluten-free diet. Gastroenterology 1964:47:573-89.

35. Freeman HJ, Whittaker JS. Nonalcoholic chronic pancreatitis with pancreatic calcification: Presenting manifestation of occult celiac disease. Can J Gastroenterol 1994;8:319-22.

36. Dickey W, Kearney N. Overweight in celiac disease: Prevalence, clinical characteristics, and effect of a gluten-free diet. Am J Gastroenterol 2006;101:2356-9.

37. Gillett HR, Freeman HJ. Serological testing for screening in adult celiac disease. Can J Gastroenterol 1999;13:265-9.

38. Dickey W, Hughes DF, McMillan SA. Disappearance of endomysial antibodies in treated celiac disease does not indicate histological recovery. Am J Gastroenterol 2000;95:712-4.

39. Tursi A, Brandimarte G, Giorgetti GM. Lack of usefulness of anti-transglutaminase antibodies in assessing histologic recovery after gluten-free diet in celiac disease. J Clin Gastroenterol 2003;37:387-91.

40. Latiff AH, Kerr MA. The clinical significance of immunoglobulin A deficiency. Ann Clin Biochem 2007;44:131-9.

41. Freeman HJ. Strongly positive tissue transglutaminase antibody assays without celiac disease. Can J Gastroenterol 2004; 18:25-8.

42. Freeman HJ. Clinical spectrum of biopsy-defined celiac disease in the elderly. Can J Gastroenterol 1995;9:42-6.

43. Pare P, Douville P, Caron D, Legace R. Adult celiac sprue: Changes in the pattern of clinical recognition. J Clin Gastroenterol $1988 ; 10: 395-400$

44. Freeman HJ. Celiac associated autoimmune thyroid disease: A study of 16 patients with overt hypothyroidism. Can J Gastroenterol 1995;9:242-6.

45. Gillett PM, Gillett HR, Israel DM, et al. High prevalence of celiac disease in patients with type 1 diabetes detected by antibodies to endomysium and tissue transglutaminase. Can J Gastroenterol 2001;15:297-301

46. Freeman HJ. Occult celiac disease in an octogenarian presenting with a small intestinal adenocarcinoma. Can J Gastroenterol 1994;8:354-57.

47. Isaacson PG, O'Connor NT, Spencer J, et al. Malignant histiocytosis of the intestine: A T-cell lymphoma. Lancet 1985;2:688-91.

48. Freeman HJ. Fulminant liver failure with necrotizing foci in the liver, spleen and lymph nodes in celiac disease due to malignant lymphoma. Can J Gastroenterol 1996;10:225-9.

49. Freeman HJ. T-cell lymphoma of the thyroid gland in celiac disease. Can J Gastroenterol 2000;14:635-6.
50. Freeman HJ. Free perforation due to lymphoma in biopsy-defined or suspected celiac disease. J Clin Gastroenterol 2003;37:299-302.

51. Hamilton I, Sanders S, Hopwood D, Bouchier IA. Collagenous colitis associated with small intestinal villous atrophy. Gut 1986;27:1394-8

52. Wolber R, Owen D, Freeman HJ. Colonic lymphocytosis in patients with celiac sprue. Hum Pathol 1990;21:1092-6.

53. Freeman HJ, Kwan WC. Occult celiac disease associated with lymphocytic sclerosing cholangitis. Can J Gastroenterol 1994;8:249-52.

54. Stancu M, De Petris, Palumbo TP, Lev R. Collagenous gastritis associated with lymphocytic gastritis and celiac disease. Arch Pathol Lab Med 2001;125:1579-84.

55. Wolber R, Owen D, DelBuono L, Appelman H, Freeman H. Lymphocytic gastritis in patients with celiac sprue or spruelike intestinal disease. Gastroenterology 1990;98:310-5.

56. Freeman HJ. Collagenous mucosal inflammatory diseases of the gastrointestinal tract. Gastroenterology 2005;129;338-50.

57. Gillett HR, Freeman HJ. Prevalence of celiac disease in collagenous and lymphocytic colitis. Can J Gastroenterol 2000;14:919-21.

58. Freeman HJ. Failure of added dietary gluten to induce small intestinal histopathological changes in patients with watery diarrhea and lymphocytic colitis. Can J Gastroenterol 1996;10:436-9.

59. Freeman HJ. Collagenous colitis as the presenting manifestation of biopsy-defined celiac disease. J Clin Gastroenterol 2004;38:664-8

60. Weinstein WM. Latent celiac sprue. Gastroenterology 1974;66:489-93

61. Mahadeva S, Wyatt JI, Howdle PD. Is a raised intraepithelial lymphocyte count with normal duodenal villous architecture clinically relevant? J Clin Pathol 2002;55:424-8.

62. Wahab PJ, Crusius JB, Meijer JW, Mulder CJ. Gluten challenge in borderline gluten-sensitive enteropathy. Am J Gastroenterol 2001;96:1464-9.

63. Janatuinen EK, Kemppainen TA, Julkunen RJ, et al. No harm from five year ingestion of oats in coeliac disease. Gut 2002;50:332-5.

64. Lundin KE, Nilsen EM, Scott HG, et al. Oats induced villous atrophy in celiac disease. Gut 2003;52:1649-52.

65. Bishop RF, Davidson GP, Holmes IH, Ruck BJ. Virus particles in epithelial cells of duodenal mucosa from children with acute non-bacterial gastroenteritis. Lancet 1973;2:1281-3.

66. Drucker MM, Polliack A, Yeivin R, Sachs TG. Immunofluorescent demonstration of enteropathogenic Escherichia coli in tissues and infants dying from enteritis. Pediatrics 1970;46:855-864.

67. Schreiber DS, Blacklow NR, Trier JS. The mucosal lesion of the proximal small intestine in acute infectious nonbacterial gastroenteritis. N Engl J Med 1973;288:1318-23.

68. Koch J, Owen RL. Small intestine pathogens in AIDS: Conventional and opportunistic. Gastrointest Endosc Clin N Am 1998;8:869-88

69. Freeman HJ, Shnitka TK, Piercey JR, Weinstein WM. Cytomegalovirus infection of the gastrointestinal tract in a patient with late onset immunodeficiency syndrome. Gastroenterology 1977;73:1397-403.

70. Joshi SN, Garvin PJ, Sunwoo YC. Candidiasis of the duodenum and jejunum. Gastroenterology 1981;80:829-33.

71. Roth RI, Owen RL, Keren DF, Volberding PA. Intestinal infection with Mycobacterium avium in acquired immune deficiency syndrome (AIDS). Histological and clinical comparison with Whipple's disease. Dig Dis Sci 1985;30:497-504.

72. Strom RL, Gruninger RP. AIDS with Mycobacterium aviumintracellulare lesions resembling those of Whipple's disease. N Engl J Med 1983;309:1323-5.

73. Dubra PM, Quigley EM, Marsh MN. Chylous ascites, intestinal lymphangiectasia and the 'yellow nail' syndrome. Gut 1985;26:1266-9.

74. Bedine MS, Yardley JH, Elliott HL, Banwell JG, Hendrix TR. Intestinal involvement in Waldenstrom's macroglobulinemia. Gastroenterology 1973;65:308-15.

75. Ravid M, Sohar E. Intestinal malabsorption: First manifestation of amyloidosis in familial Mediterranean fever. Report of two cases. Gastroenterology 1974;66:446-9.

76. Greenwood N. The jejunal mucosa in two cases of A-betalipoproteinemia. Am J Gastroenterol 1976;65:160-2. 
77. O'Brien BD, Shnitka TK, McDougall R, et al. Pathophysiologic and ultrastructural basis for intestinal symptoms in Fabry's disease. Gastroenterology 1982;82:957-62.

78. Freeman HJ. Sulindac-associated small bowel lesion. J Clin Gastroenterol 1986;8:569-71.

79. Ziegler TR, Fernandez-Estivariz C, Gu LH, Fried MW, Leader LM. Severe villus atrophy and chronic malabsorption induced by azathioprine. Gastroenterology 2003;124:1950-7.

80. Sukhabote J, Freeman HJ. Granulomatous (Crohn's) disease of the upper gastrointestinal tract: A study of 22 patients with mucosal granulomas. Can J Gastroenterol 1993;7:605-9.

81. Catassi C, Fabiani E, Iacono G, et al. A prospective double-blind, placebo-controlled trial to establish a safe gluten threshold for patients with celiac disease. Am J Clin Nutr 2007;85:160-6.

82. Freeman HJ. Lymphoproliferative and intestinal malignancies in 214 patients with biopsy-defined celiac disease. J Clin Gastroenterol 2004;38:429-34.

83. Weinstein WM, Saunders DR, Tytgat GN, Rubin CE. Collagenous sprue - an unrecognized type of malabsorption. N Engl J Med 1970;283:1297-301.
84. Freeman HJ. Hyposplenism, antiendomysial antibodies and lymphocytic colitis in collagenous sprue. Can J Gastroenterol 1999;13:347-50. (Erratum in 1999;13:455).

85. Robert ME, Ament ME, Weinstein WM. The histologic spectrum and clinical outcome of refractory and unclassified sprue. Am J Surg Pathol 2000;24:676-87.

86. Freeman HJ. Collagenous sprue associated with an extensive T-cell lymphoma. J Clin Gastroenterol 2003;36:144-6.

87. Matuchansky C, Colin R, Hemet J, et al. Cavitation of mesenteric lymph nodes, splenic atrophy, and a flat small intestinal mucosa. Report of six cases. Gastroenterology 1984;87:606-14.

88. Cellier C, Patey N, Mavieux L, et al. Abnormal intestinal intraepithelial lymphocytes $\mathrm{n}$ refractory sprue. Gastroenterology 1998;114:471-81.

89. Verkarre V, Romana SP, Cellier C, et al. Recurrent partial trisomy 1q22-q44 in clonal intraepithelial lymphocytes in refractory celiac sprue. Gastroenterology 2003;125:40-6.

90. Gass J, Bethune MT, Siegel M, Spencer A, Khosla C. Combination enzyme therapy for gastric digestion of dietary gluten in patients with celiac sprue. Gastroenterology 2007;133:472-80. 


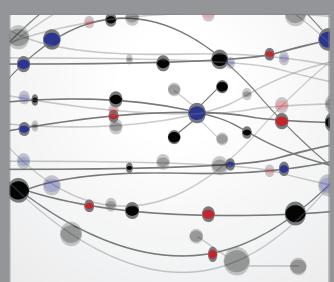

The Scientific World Journal
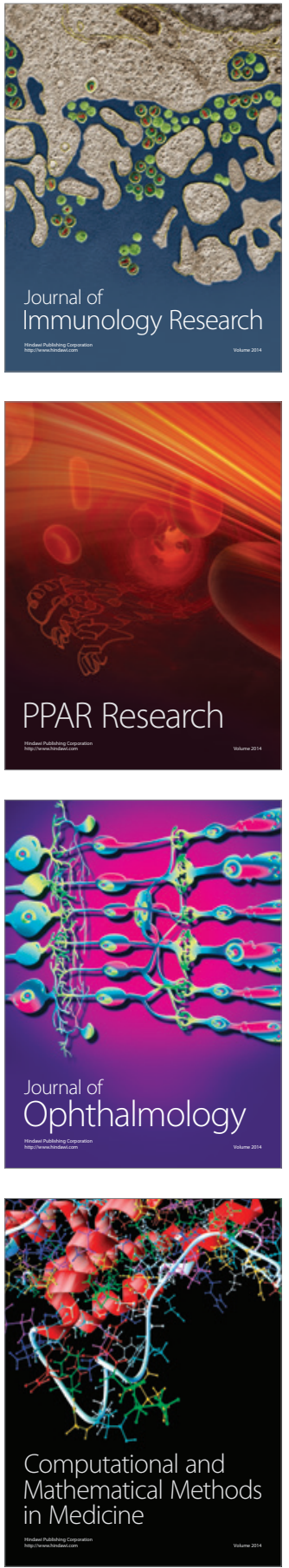

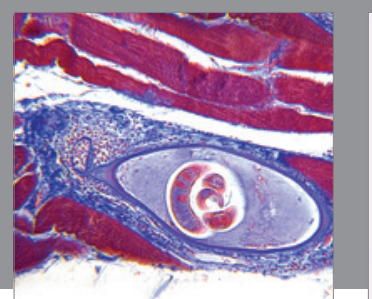

Gastroenterology Research and Practice

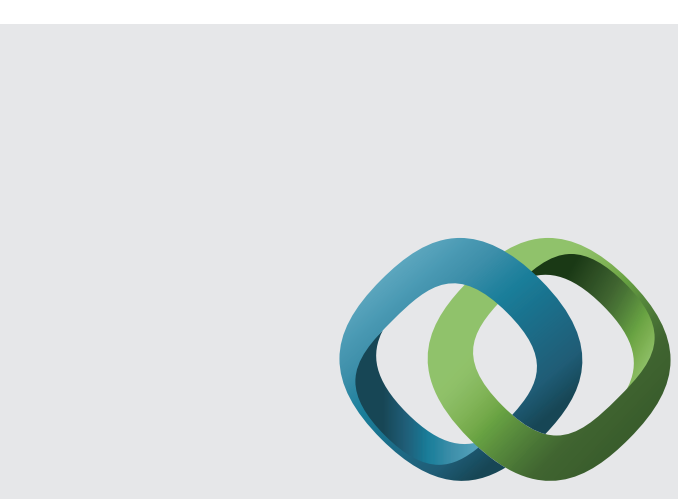

\section{Hindawi}

Submit your manuscripts at

http://www.hindawi.com
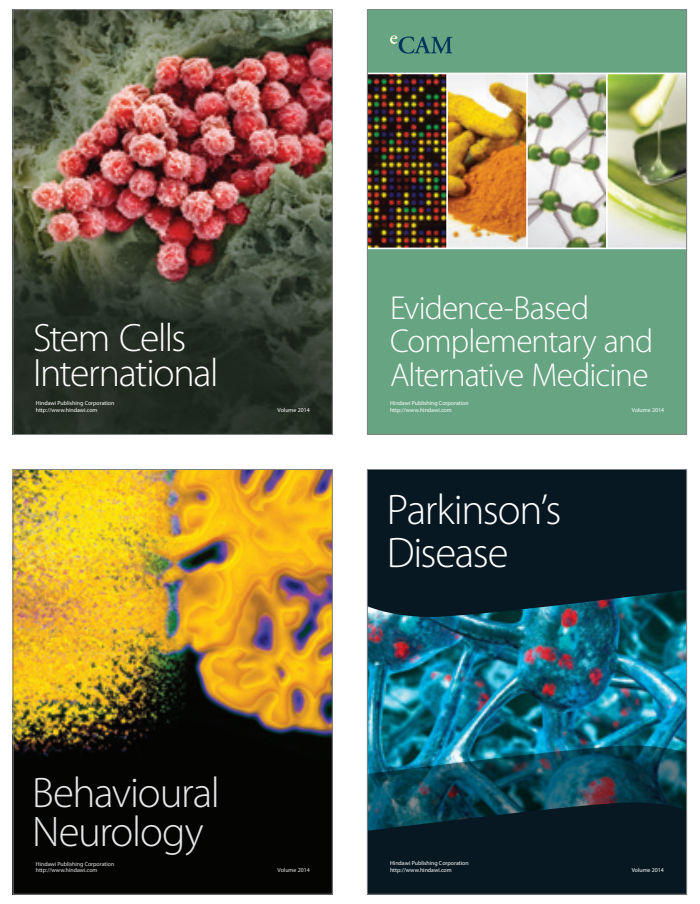
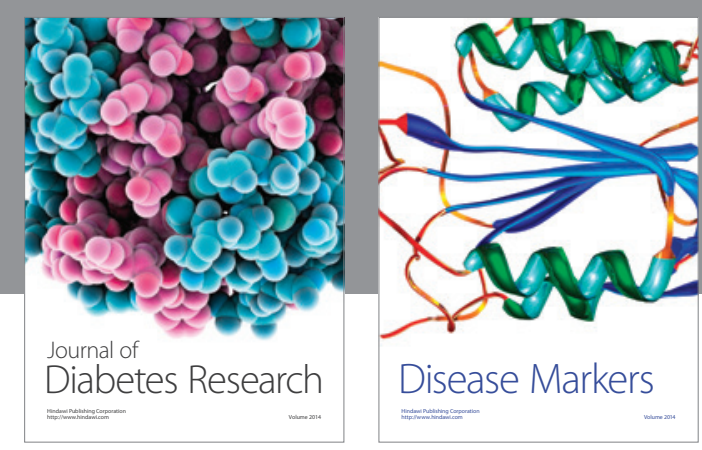

Disease Markers
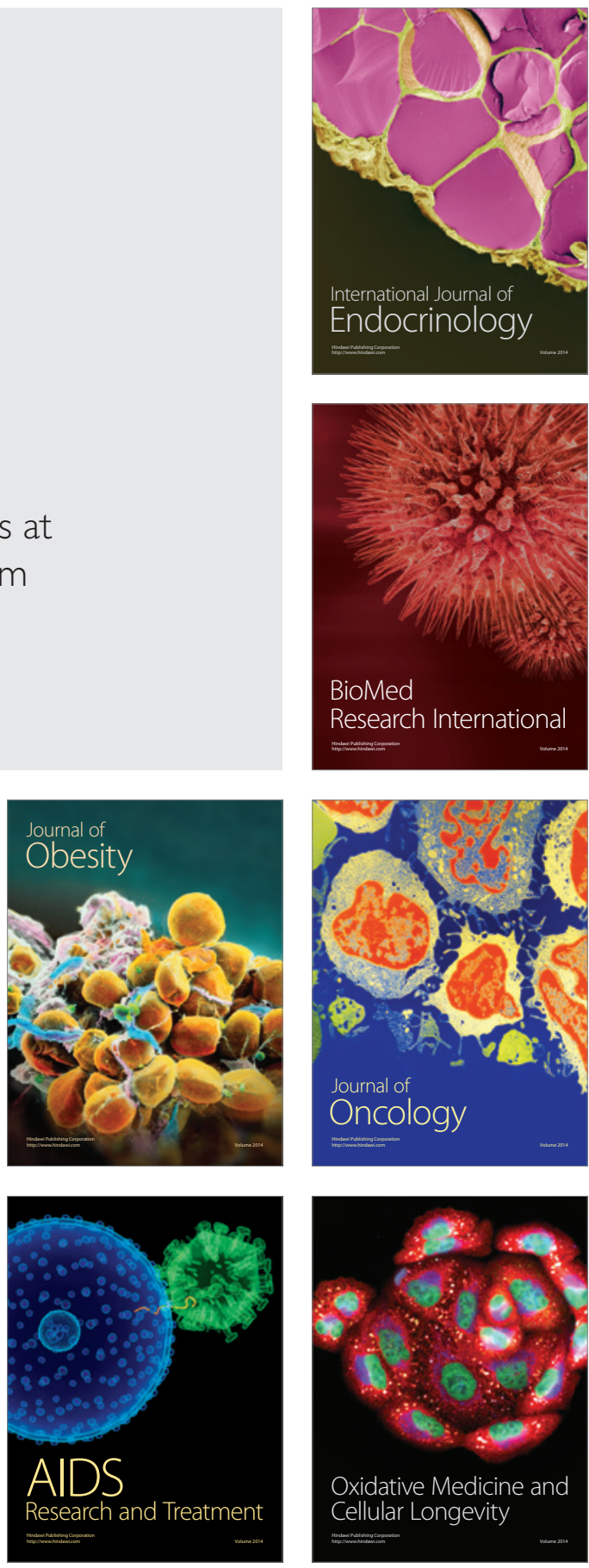